\title{
Responses to COVID-19 in Higher Education: Students' Learning Experience Using Microsoft Teams versus Social Network Sites
}

\author{
Abu Elnasr E. Sobaih 1,2,*(D), Amany E. Salem ${ }^{3,4}$, Ahmed M. Hasanein $^{2}(\mathbb{D}$ and Ahmed E. Abu Elnasr 5 \\ 1 Management Department, College of Business Administration, King Faisal University, \\ Al-Hassa 31982, Saudi Arabia \\ 2 Hotel Management Department, Faculty of Tourism and Hotel Management, Helwan University, \\ Cairo 12612, Egypt; ahmed_hasanein@fth.helwan.edu.eg \\ 3 Social Studies Department, College of Arts, King Faisal University, Al-Ahsa 31982, Saudi Arabia; \\ asalem@kfu.edu.sa \\ 4 Tourism Studies Department, Faculty of Tourism and Hotel Management, Helwan University, \\ Cairo 12612, Egypt \\ 5 Higher Institute for Specific Studies, Future Academy, Cairo 11771, Egypt; dr.ahmed.abulnasr@fa-hiss.edu.eg \\ * Correspondence: asobaih@kfu.edu.sa
}

Citation: Sobaih, A.E.E.; Salem, A.E.; Hasanein, A.M.; Elnasr, A.E.A. Responses to COVID-19 in Higher Education: Students' Learning Experience Using Microsoft Teams versus Social Network Sites. Sustainability 2021, 13, 10036. https://doi.org/10.3390/su131810036

Academic Editors: Sébastien Jacques and Abdeldjalil OUAHABI

Received: 19 August 2021

Accepted: 2 September 2021

Published: 8 September 2021

Publisher's Note: MDPI stays neutral with regard to jurisdictional claims in published maps and institutional affiliations.

Copyright: (c) 2021 by the authors. Licensee MDPI, Basel, Switzerland. This article is an open access article distributed under the terms and conditions of the Creative Commons Attribution (CC BY) license (https:// creativecommons.org/licenses/by/ $4.0 /)$.

\begin{abstract}
The long-lasting impact of COVID-19 forced governments to continue with distance learning. Due to the absence of a formal digital learning management system (DLMS), public universities in many countries adopted social network sites (SNSs), e.g., Facebook and WhatsApp, and/or digital communication platforms, e.g., Microsoft (MS) Teams and Zoom for teaching and learning. This research investigates students' learning experiences and responses to course/s incorporating SNSs and MS Teams as a sole distance learning platform during COVID-19. An online, pre-tested, questionnaire was used, directed at bachelor students in public institutions in Egypt, offering tourism and hotel programs, who received their courses using both SNSs and MS Teams. The results showed that the usage of both SNSs and MS Teams helped students to access information and learning resources, have good impact on their knowledge construction and critical refection, and report overall positive learning experience. The results of paired-samples t-test showed statistically significant differences between students' experiences of course/s incorporating SNSs and MS Teams. However, students recorded limited support by their educators and peers and low participation in course activities that adopted MS Teams. They also reported poor assessment and feedback with course/s that incorporated SNSs. Hence, several implications for scholars, policymakers, and educators were presented for achieving better learning experience and to cope with the pandemic or similar crises, especially in universities with poor infrastructure, including unavailability of DLMS.
\end{abstract}

Keywords: COVID-19; Microsoft (MS) Teams; social network sites (SNSs); distance learning; students' learning experience; higher education

\section{Introduction}

The worldwide pandemic of novel coronavirus disease (COVID-19) has posed unprecedented challenges to traditional or face-to-face education. Countries has made various attempts to deter virus outbreak, such as reducing large gatherings and ensuring physical social "place" distance. In consequence, governments have shifted education from face-to-face to distance learning. However, most public universities in developing nations, e.g., Egypt, are suffering from a lack of technological platforms and formal digital learning management systems (DLMS) for communication with students, e.g., Blackboard. Hence, they do not have the full capabilities to support the online learning process [1-3].

The initial wave of the pandemic of COVID-19, in December 2019 and first quarter of 2020, has pushed policymakers and public universities in higher education to search 
for quick alternatives to the traditionally based learning system of physical classroom. Various universities, for instance in Egypt, have encouraged their faculty members to use free collaborative digital platforms, e.g., Google Classroom and Zoom [3]. Furthermore, social network sites (SNSs), i.e., Facebook, WhatsApp, adopted by institutions and their faculty members to communicate with their students [2,3]. However, some issues emerged about the quality of distance learning, the learning process during this critical period and achieving the intended learning outcomes (ILOs) of courses (i.e., knowledge, attitude, and skills) $[4,5]$.

The long-lasting impact of COVID-19 obliged governments to continue with distance education. Thus, universities have adopted distance learning from 2020 onward and have continued with either full or partial (blended) online system. In this context, the Ministry of Higher Education and Scientific Research in Egypt (MHESR) adopted distance/online learning in public universities for the academic year 2019-2020 to date. For this academic year and directly amid the COVID-19 pandemic, in the second semester of 2019-2020, universities adopted SNSs as formal and sole distance learning platforms [3]. Blended learning was then adopted from academic year 2020-2021 onward. In an attempt to meet this blended learning for academic year 2020-2021, the Egyptian government has worked closely with Microsoft Corporation to adapt Microsoft (MS) Teams for academic-related purposes, especially as a teaching and learning tool.

Although distance education helps students feel less hesitant and/or shy to ask questions, there is evidence that students feel less engaged in distance learning, which requires more effort from their educators [6]. Distance education allows students to access information and knowledge at their convenience [6]. It also can help in achieving the same final score and overall performance similar to face-to-face teaching [4]. However, research (e.g., [3-5]) also confirmed that practical work and projects, which necessitate the use of specific laboratory equipment, are not well suited to distance learning. Distance learning has become the sole option for education amid COVID-19; however, choosing a tool for distance learning necessitates the consideration of criteria such as efficiency, service quality, data protection, parameterization options for different types of users, user ergonomics, and cost [6].

This research investigates students' learning experience and their responses to course/s incorporating two different learning platforms: SNSs for the first phase (academic year 2019-2020, especially the second semester,) and MS Teams for the second phase (academic year 2020-2021) during COVID-19. Both SNSs and MS Teams were used for the first time for distance learning during COVID-19. The research attempts to investigate student's learning experience with MS Teams compared to SNSs, i.e., WhatsApp and Facebook, for teaching and learning purposes in public universities, especially post the COVID-19 pandemic. These public universities did not have a robust use of LMS and were reliant on in-class communication prior to COVID-19. Hence, they adopted SNSs and then MS Teams for sustaining their learning process and overall higher education. The research results have implications for other public institutions of similar characteristics and for scholars in relation to the future of higher education, especially in developing-country contexts. The guiding research questions for this research were as follows:

1. What is the extent to which students in public higher education institutions in Egypt adopted SNSs and MS Teams for teaching and learning purposes during COVID-19?

2. How did students perceive their learning experience in the course/s incorporating SNSs and MS Teams during COVID-19?

3. Were there any differences in students' experience regarding the usage of MS Teams and SNSs for teaching and learning purposes during COVID-19?

4. What were the implications for scholars, policymakers, and educators in relation to the usage of MS Teams and SNSs for teaching and learning purposes? 


\section{Literature Review}

\subsection{Responses to COVID-19 in Higher Education}

Globally, the COVID-19 pandemic has had a transformative influence on higher education institutions around the world. Institutions had to respond to the pandemic with emergency distance learning, indicating a quick shift from face-to-face classes to distance learning platforms $[7,8]$. Thus, higher education institutions converted their traditional classes from face-to-face to full online learning from the winter semester of academic year 2019/2020 onward [7]. In this context, the remote system of online teaching and learning has grown-up to sustain educational dynamics replacing traditional educational methods [9]. Thus, access to distance learning has become an urgent response for ensuring inclusive and equitable education [10].

Higher educational institutions are grappling with how to adapt to this change while also attempting to select the appropriate technologies and methods for educating and engaging their students. Digital technology and communication applications facilitate distance learning and ensure sustainable education amid and post the COVID-19 pandemic [11,12]. Nonetheless, universities in developing countries are lacking in technological platforms and formal DLMS [3] and they were struggling to provide quality education during this time of the pandemic. Hence, policymakers in these countries encouraged their faculty members to rely on either collaborative digital platforms (e.g., Google Classroom, Cisco WebEx, YouTube, Zoom) or SNSs (e.g., Facebook and WhatsApp) for academicrelated communication $[3,4]$.

\subsection{Social Network Site Usage for Teaching and Learning in Higher Education}

Research to date (see for example $[1,3,13,14]$ ) has shown that SNSs were successfully adopted for sustaining academic communication, especially as a learning and teaching tool. Facebook, WhatsApp, YouTube, and Wikipedia are among the most popular social media platforms for academic communication [15]. Other studies confirmed that Facebook was the most frequently adopted SNS for academic purposes, including teaching and learning purposes [3,16-18]. Studies (e.g., [19-21]) have shown several advantages for SNS usage in higher education such as positive academic performance, informal scholarly communication, community building, maintaining trust and satisfaction, connectivity as well as developing students' learning experience.

Studies (e.g., [22]) have valued SNS usage in increasing student engagement and influencing positive student learning experiences. Other studies (e.g., $[13,18,23,24]$ ) were carried out to assess the efficacy of SNSs as a tool in improving student integration in higher education. Recent research has confirmed that SNSs is considered an effective tool for increasing students' engagement [18], improving student awareness of their learning experience [25,26], and improving students' performance [20,23,24]. However, other studies reported that the usage of social media has been associated with students' negative academic performance [27]. Additionally, faculty members confirmed several barriers or challenges for using SNSs for academic purposes, such as limited support from institutions, privacy and security, digital divide, loss of control and monitoring, poor IT support, limited awareness about the role of SNSs, and poor infrastructure $[1,3,28]$.

\subsection{Microsoft Teams as an E-Learning Platform for Higher Education Institutions}

Post COVID-19, higher education institutions were forced to officially communicate online for academic-related purposes [29]. However, due to the unavailability of online DLMS, such as Blackboard, various efforts have been made by policymakers to ensure the learning process continues in the academic year of 2020/2021. Therefore, educational decision-makers in some developing countries, such as Egypt, have been exploring a variety of communication platforms in order to re-open their institutions. In consequence, the MHESR in Egypt has announced a partnership with Microsoft Corporation to use MS Teams for teaching and learning purposes. MS Teams is an integrated communication platform with Microsoft Office 365. This technology tool could work with the entire institution or 
with individual programs. In addition to its usage in business settings, Teams has been used with face-to-face, hybrid, and online courses [4,5,29]. The application contains some features such as meetings, video conferencing, and file storage. MS Team's members can create virtual classes and manage them just like real classes, where students can interact with their classmates and teachers. This interaction can take place via online class meetings, chat, post, or online assessment [30-32]. Teams enables students and instructors to interact online in ways that are not typically seen on a traditional LMS [29]. Moreover, MS Teams is considered as supper application because it integrates many different apps, e.g., online meeting, videos, chats, and assessment, into one program [30]. Several studies have been conducted about students' perceptions of online learning (e.g., [33-36]). On the contrary, limited but growing, studies were conducted about students' perceptions on collaborative digital or communication platforms such as: Zoom [37], Google Classroom [35], and MS Teams [38,39].

Previous studies (e.g., [39-41]) have been conducted to study students' perceptions of using MS Teams application in online learning. A recent study [39] showed that during the COVID-19 pandemic, students had a positive impression of MS Teams usage in online learning. The same study [39] showed that MS Teams has several advantages such as, students' motivation to be more disciplined, easily interaction with peers and lecturers, and optimal support for a proper learning environment for students. In that sense, another study [40] added that MS Teams is a better tool for online learning in comparison with other communication platforms. Another recent study [40] confirmed MS Teams as a good application for online learning, which is efficient and effective and improves students enthusiasm in learning. On the other hand, the same studies reported some barriers for using the MS Teams such as lack of explanation regarding how to use this platform, number of users or internet quota, and its need for adequate internet network [39]. Furthermore, Karthikeyan [40] argued that MS Teams is not effective for laboratory lessons as well as that MS Teams is not appropriate while submitting long answers, such as those to essay questions. A study [42] also reported other disadvantages for using MS Teams as an online learning platform such as lack of interaction between students themselves and their educators as well, which leads to social isolation; lack of communication that usually leads to mental issue such as negative thoughts; and lack of self-motivation with bad time management. Additionally, there are some problems faced by MS Teams users such as insufficient internet facilities, invisible image display, and unclear voice [41]. To that end, the use of MS Teams as an online learning tool is still in its infancy, especially in higher education.

\section{Methodology}

\subsection{Population and Sample}

The population of this research is bachelor students in public institutions offering a tourism and hotel degree in Egypt. These institutions were using SNSs for teaching and learning purposes amid COVID-19 during academic year 2019-2020, especially the second semester, and MS Teams during academic year 2020-2021. Students, who were part of these learning experiences and received courses incorporating both SNSs and MS Teams, were invited to participate in the study via an online questionnaire. All proposed guidelines for properly applying the online questionnaire [43] were followed. The sample adopted in this research is a simple random sample. The online questionnaire was sent directly to a random sample of students, who participated in these two experiences, in Tourism Studies and Hotel Management Departments at the Colleges of Tourism and Hotels via WhatsApp and Facebook groups. The link of the questionnaire was also sent to students via their personal email. These students were accessed directly by the research team members who were also part of this learning experience. Only 387 forms were fully completed and valid for analysis. This sample size was found sufficient for data analysis and compared favorably with the sample of similar research studies (e.g., $[1,13,16])$. The data were collected after students finished their second semester study for the academic 
year 2020-2021. The data collection took 50 days, which started form the middle of June 2021. Students were ensured that the study was for research purposes. They were also ensured that the study is anonymous, and hence no personal information was collected from them. Figure 1 presents a summary of the research methodology framework.

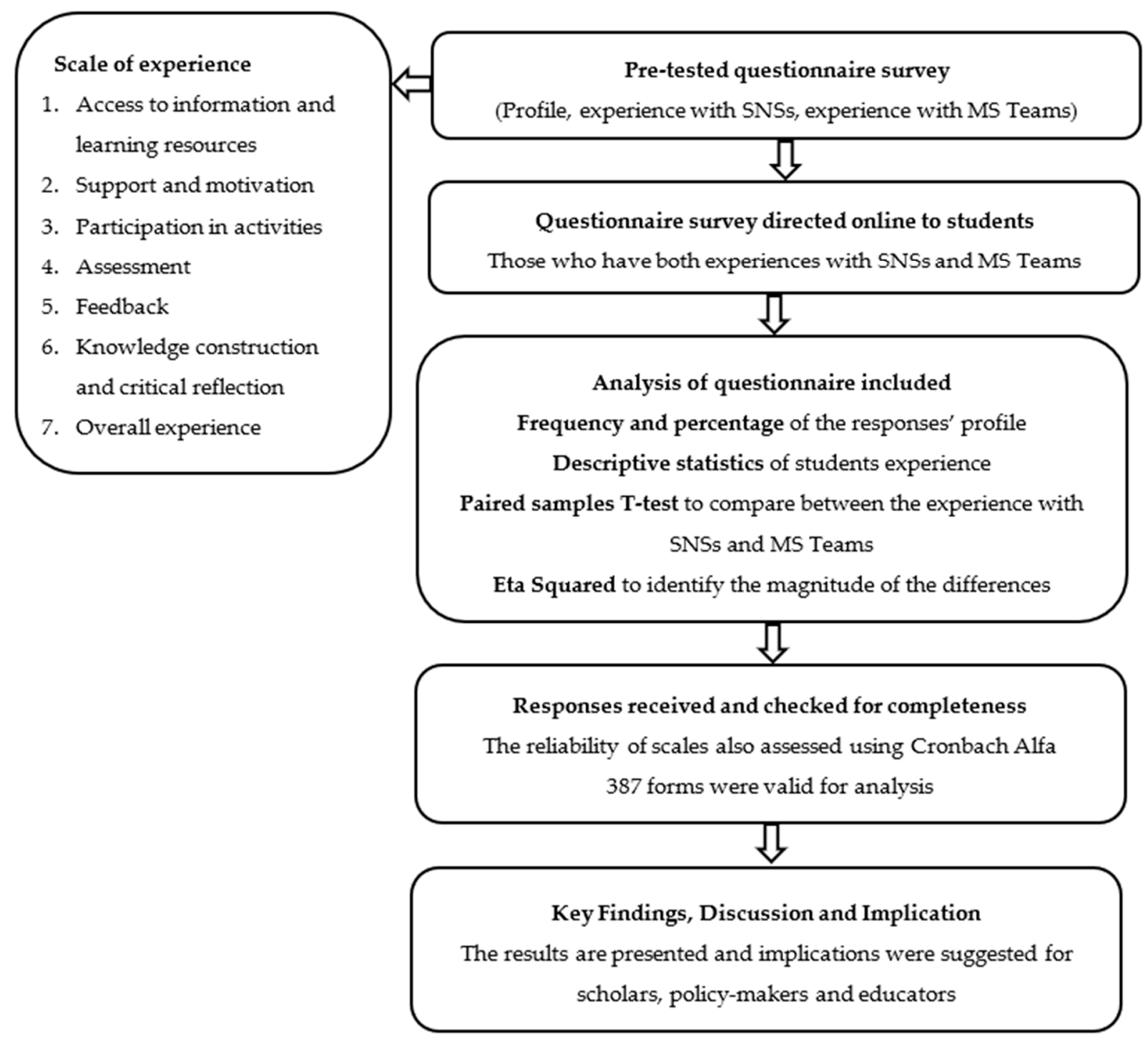

Figure 1. The framework of the research methodology.

\subsection{Research Instrument}

The questionnaire was divided into four sections. The first section included the profile of respondents, i.e., gender, age, devices used to connect online, frequency of using SNSs for academic-related purposes, and their previous experience with the MS Teams application. Sections two and three investigated students' experience with redesigned courses using SNSs and MS Teams, respectively. Each section included 30 pre-tested items on a five-point Likert scale, where $1=$ strongly disagree and $5=$ strongly agree. These items were divided under seven main variables that shape students experience: access to information and learning resources (four items), support (four items), participation (four items), assessment (five items), feedback (four items), critical reflection (four items), and overall perceptions of SNSs or MS Teams usage in course/s (five items). The items of learning experience were drawn from a previous study [44], which was examined in other studies [15]. Section four included two open questions about their experience of SNSs or MS Teams usage in the 
course/s. The reliability of scale was ensured using Cronbach's alpha. The reliability of scale was between 0.86 and 0.92 , which was above the acceptable level of 0.70 for all items of the scale adopted [45].

\subsection{Data Analysis}

The study used computer software of (IBM) Statistical Package for Social Science (SPSS) version 26. Frequencies and percentage were used to analyze the profile of respondents. Descriptive statistics, i.e., mean and standard deviation, were used to analyze students' learning experiences and responses to courses, which used SNSs and MS Teams for teaching and learning. Paired-sample t-test was adopted to understand whether there was a statistically significant difference between students' experiences with SNSs and MS Teams. According to the SPSS Survival Manual [46], paired-sample t-test was used to analyze the data collected from one group of participants on two different occasions. In this research, data were collected from students who had experiences of both SNSs and MS Teams, and thus the paired-sample t-test was adopted for analysis. However, paired-samples t-test does not show the magnitude of the interventions' effects, and hence, effect size, i.e., eta squared, should be calculated [46]. Therefore, eta squared was used to identify the magnitude of the differences between SNSs and MS Teams.

\section{Results}

\subsection{Profile of Respondents}

Table 1 summarizes the profile of the questionnaire's participants, i.e., gender, age, devices used to connect online, frequency of using SNSs for academic-related purposes, and their previous experience with the MS Teams application. The proportion of males who participated in the current study was nearly equal to that of females. The vast majority of students were under 30 years of age, i.e., relatively young. This is because there is no gap between higher education and secondary school in Egypt according to the Egyptian educational system, which agrees with previous studies [13].

Table 1. The profile of respondents.

\begin{tabular}{cccc}
\hline Item & & Frequency & \% \\
\hline \multirow{2}{*}{ Gender } & Male & 185 & 47.8 \\
& Female & 202 & 52.2 \\
Age & Less than 20 years & 159 & 41.1 \\
& 20-30 years & 221 & 57.1 \\
& Over 30 years & 7 & 1.8 \\
& Smartphones & 368 & 95.1 \\
Appliances used to connect & Laptops & 272 & 70.3 \\
& iPad/Tablets & 135 & 34.9 \\
Frequency of using SNSs for & Desktop & 92 & 23.8 \\
academic-related purposes & Daily & 380 & 98.2 \\
MT previous experience & Weekly & 7 & 1.8 \\
& Yes & 76 & 19.6 \\
& No & 311 & 80.4 \\
\hline
\end{tabular}

Almost all students (98.2\%) used SNSs for academic-related purposes on a daily basis, which supports previous studies (e.g., [3,18]), whereas a very slight proportion $(1.8 \%)$ used them on weekly basis. Students used different devices to keep active online, albeit the vast majority of respondents (95.1\%) used their smart phones. Next to smart phones, laptops were the most used devices by students $(70.3 \%)$, followed by iPads or tablets $(34.9 \%)$, while only $23.8 \%$ of participants accessed the internet using desktops. Although students were active on daily basis using SNSs for academic-related purposes, only small proportion of respondents (19.6\%) reported previous experience with MS Teams. 


\subsection{Students' Experiences with Courses Incorporating SNSs and MS Teams}

The results of descriptive statistics in Table 2 showed that students had almost the same high mean score for SNSs and MS Teams in relation to their access to information and learning resources. This means students perceive both SNSs and MS Teams as adequate learning resources. Students agreed that both SNSs and Teams facilitated discussions and assignment or project work. In this context, students also agreed that the design of their course was interesting (Table 2). The results also showed that SNSs and MS Teams had nearly the same high mean scores for knowledge construction and critical reflection. This means that students agreed that both SNSs and MS Teams helped them to articulate and present their ideas and feel confident in using information acquired from the course to solve problems. Additionally, the results showed that students agreed that they have positive overall perceptions of SNSs and MS Teams usage for teaching and learning. They were overall satisfied with the experience of both SNSs and MS Teams.

Table 2. Descriptive statistics of students' experience with SNSs and MS Teams.

\begin{tabular}{|c|c|c|c|c|}
\hline \multicolumn{2}{|c|}{ SNSs } & \multirow{2}{*}{ Item } & \multicolumn{2}{|c|}{ MS Teams } \\
\hline$\mu$ & $\sigma$ & & $\mu$ & $\sigma$ \\
\hline \multicolumn{5}{|c|}{ Access to Information and Learning Resources } \\
\hline 4.434 & 0.6338 & I had access to adequate learning resources relevant to the course/s. & 4.364 & 0.5231 \\
\hline 4.344 & 0.6261 & The course/s facilitates discussions and assignments or project work. & 4.277 & 0.6304 \\
\hline 4.408 & 0.6468 & I was provided with sufficient information to get on with my studies. & 4.346 & 0.6226 \\
\hline 4.344 & 0.6261 & I did find the design of the course/s interesting. & 4.434 & 0.6338 \\
\hline \multicolumn{5}{|c|}{ Support and Motivation } \\
\hline 4.408 & 0.5171 & I received appropriate mentoring in the course/s. & 1.408 & 0.5228 \\
\hline 4.277 & 0.6062 & The coordinator was responsive to my learning needs of the course/s. & 1.413 & 0.5187 \\
\hline 4.346 & 0.6175 & The course/s structure enhanced my ability to successfully achieve the course outcome. & 1.408 & 0.5228 \\
\hline 4.496 & 0.5231 & The course/s has helped me to communicate successfully with other students. & 1.388 & 0.4878 \\
\hline \multicolumn{5}{|c|}{ Participation in Course Activities } \\
\hline 4.299 & 0.5171 & I did find the online activities of the course/s engaging. & 1.408 & 0.5228 \\
\hline 4.388 & 0.6062 & I felt encouraged by the learning activities provided. & 1.388 & 0.4878 \\
\hline 4.379 & 0.6175 & I did feel encouraged to learn by engaging in the group activities. & 1.408 & 0.5228 \\
\hline 4.364 & 0.5231 & I feel a greater sense of community with my peers. & 1.388 & 0.4878 \\
\hline \multicolumn{5}{|c|}{ Assessment } \\
\hline 1.408 & 0.5228 & The online assignments have enhanced my ability to judge my own work. & 4.344 & 0.6261 \\
\hline 1.413 & 0.5187 & Assessment in this course/s contributed to my learning of the subject. & 4.434 & 0.6338 \\
\hline 1.364 & 0.4819 & Assessment items were used to improve my learning in this course/s. & 4.364 & 0.5231 \\
\hline 1.408 & 0.5228 & The assessment criteria were clearly communicated to me. & 4.369 & 0.6319 \\
\hline 1.413 & 0.5187 & Preparing for the assessment activities did help my learning of the course/s' goals. & 4.277 & 0.6304 \\
\hline \multicolumn{5}{|c|}{ Feedback } \\
\hline 1.408 & 0.5228 & I have been provided with feedback in this course/s. & 4.344 & 0.6261 \\
\hline 1.388 & 0.5187 & I was given adequate feedback about how well I was doing in the course/s. & 4.439 & 0.6343 \\
\hline 1.408 & 0.5228 & The feedback on my work gave me direction on how I needed to improve. & 4.364 & 0.5231 \\
\hline 1.413 & 0.5187 & I used the feedback to improve on the quality of my assignments. & 4.277 & 0.6304 \\
\hline \multicolumn{5}{|c|}{ Critical Reflection and Knowledge Construction } \\
\hline 4.379 & 0.6175 & I feel more confident in articulating and presenting design ideas. & 4.496 & 0.6038 \\
\hline 4.364 & 0.5231 & I feel more confident to build and strengthen online community. & 4.515 & 0.5905 \\
\hline 4.277 & 0.6304 & I feel confident to explore more content of interest of the course/s. & 4.346 & 0.6226 \\
\hline 4.346 & 0.6226 & I felt confident in using knowledge acquired from the course to solve problems. & 4.434 & 0.6338 \\
\hline \multicolumn{5}{|c|}{ Overall Perception } \\
\hline 4.434 & 0.6338 & The class interactions online support my learning experience. & 4.496 & 0.6038 \\
\hline 4.344 & 0.6261 & I feel a greater sense of community with my class peers. & 4.519 & 0.5905 \\
\hline 4.408 & 0.6468 & I have learnt a great deal from my peers through the online interaction activities. & 4.478 & 0.6287 \\
\hline 4.344 & 0.6261 & I feel encouraged to learn more about the subject through the online activities. & 4.434 & 0.6338 \\
\hline 4.434 & 0.6338 & I enjoyed the activities because they helped me to understand the subject better. & 4.519 & 0.5905 \\
\hline
\end{tabular}

The results, however, showed that only SNSs had a high mean score in relation to support received from educators and peers and their participation in the courses' activities 
compared to MS Teams, which had a low mean score for these two aspects. This means that students perceived appropriate mentoring and better support from other students on SNSs compared to on MS Teams. They also had more engagement in activities, including group activities, on SNSs compared to on MS Teams. One the other side, MS Teams had a higher mean score regarding both assessments and feedback than SNSs did. This means that students agreed that SNSs assessments and feedback are fewer and poor compared to those on MS Teams. Students preferred to use MS Teams rather than SNSs to proceed with online assignments and get feedback.

Paired-samples t-test was conducted to compare students' experiences and their perceptions of SNSs and MS Teams as learning tools in relation to seven major variables: access to information and learning resource, support and motivation, participation in course activities, assessment, feedback, critical reflection and knowledge construction, and students' overall perceptions and experience. The results showed statistically significant differences between experiences of courses in relation to the seven major variables (Table 3). Significant differences were obvious as follows: access to information and learning resource $(t=2318, p<0.022)$, support and motivation $(t=95.776, p<0.001)$, participation in course activities $(t=127.802, p<0.001)$, assessment $(t=-132.875, p<0.001)$, feedback $(t=-134.066$, $p<0.001)$, critical reflection and knowledge construction $(t=-6245, p<0.001)$, and overall experience $(t=-4945, p<0.001)$. The results of eta-squared statistics indicated a very large effect size between SNSs and MS Teams in relation to four main items: support $\left(\eta^{2}=0.95\right)$, participation $\left(\eta^{2}=0.97\right)$, assessment $\left(\eta^{2}=0.97\right)$, and feedback $\left(\eta^{2}=0.97\right)$. The results showed very small effect size in relation to the other three main items: access to information and learning resources, knowledge construction and critical reflection, and overall perceptions (Table 3).

Table 3. The results of paired-samples t-test statistics and eta squared.

\begin{tabular}{|c|c|c|c|c|c|c|c|c|}
\hline & & $\mu$ & $\mathrm{n}$ & $\sigma$ & $t$ & $d f$ & $p^{*}$ & $\eta^{2}$ \\
\hline Pair 1 & $\begin{array}{l}\text { SNSs access to information and } \\
\text { learning resources } \\
\text { MT access to information and } \\
\text { learning resources }\end{array}$ & $\begin{array}{l}17.5297 \\
17.4212\end{array}$ & 387 & $\begin{array}{l}2.35700 \\
1.79979\end{array}$ & 2.318 & 386 & 0.021 & 0.01 \\
\hline Pair 2 & $\begin{array}{l}\text { SNS support } \\
\text { MT support }\end{array}$ & $\begin{array}{l}17.5271 \\
5.6176\end{array}$ & 387 & $\begin{array}{l}2.27652 \\
1.32864\end{array}$ & 95.776 & 386 & 0.000 & 0.95 \\
\hline Pair 3 & $\begin{array}{l}\text { SNS participation } \\
\text { MT participation }\end{array}$ & $\begin{array}{l}17.4315 \\
5.5917\end{array}$ & 387 & $\begin{array}{l}1.17281 \\
1.42833\end{array}$ & 127.802 & 386 & 0.000 & 0.97 \\
\hline Pair 4 & $\begin{array}{l}\text { SNS assessment } \\
\text { MT assessment }\end{array}$ & $\begin{array}{c}7.0078 \\
21.7881\end{array}$ & 387 & $\begin{array}{l}1.64220 \\
1.64508\end{array}$ & -132.875 & 386 & 0.000 & 0.97 \\
\hline Pair 5 & $\begin{array}{l}\text { SNS feedback } \\
\text { MT feedback }\end{array}$ & $\begin{array}{c}5.6176 \\
17.4238\end{array}$ & 387 & $\begin{array}{l}1.32864 \\
1.32190\end{array}$ & -134.066 & 386 & 0.000 & 0.97 \\
\hline Pair 6 & $\begin{array}{l}\text { SNS knowledge construction and } \\
\text { critical reflection } \\
\text { MT knowledge construction and } \\
\text { critical reflection }\end{array}$ & $\begin{array}{l}17.3669 \\
17.7959\end{array}$ & 387 & $\begin{array}{l}1.52857 \\
1.80017\end{array}$ & -6.245 & 386 & 0.000 & 0.09 \\
\hline Pair 7 & $\begin{array}{l}\text { Overall perception } \\
\text { Overall perception }\end{array}$ & $\begin{array}{l}21.9638 \\
22.4470\end{array}$ & 387 & $\begin{array}{l}2.38925 \\
1.76440\end{array}$ & -4.945 & 386 & 0.000 & 0.06 \\
\hline
\end{tabular}

$\mu=$ mean; $\mathrm{n}=$ number of respondents; $\sigma=$ standard division; $t=1 / 4$ paired $\mathrm{t}$-test; $\eta^{2}=1 / 4$ setsquare; ${ }^{*}$ value $<0$. The formula for eta squared is $\eta^{2}=t^{2} / t^{2}+(\mathrm{n}-1)$.

\section{Discussion and Implication}

The current research study is a response to the use of SNSs, especially WhatsApp and Facebook, and then MS Teams for teaching and learning in public higher education institutions in Egypt offering a tourism and hotels degree amid the COVID-19 pandemic. Distance education is not a new concept since it has been used by prestigious universities around the world for decades and has been adopted globally to cope with COVID-19 [4,5]. It is crucial however, to assess how public universities in developing counties, such as, Egypt, adopted distance learning and how students perceived this for achieving better 
learning experiences. Due to poor infrastructure and unavailability of formal digital LMS in these public institutions, educators adopted SNSs for teaching and learning purposes amid the pandemic [3,4]. Educators redesigned their courses to interact with their students on WhatsApp and Facebook and achieve learning outcomes during the second semester for academic year 2019-2020. Due to the long-lasting pandemic, the higher education leaders in Egypt asked their educators to adopt MS teams for teaching and learning during academic year 2020-2021. Hence, we have two different experiences (courses provided using SNSs and MS Teams). The current research assessed students' learning experience with these two different platforms (SNSs versus MS Teams), which were adopted amid COVID-19 in public universities.

The results of current research support the previous studies (e.g., $[3,4,18])$ that both SNSs and MS Teams helped students to gain appropriate learning experience. Students positively perceived courses incorporating either SNSs or MS Teams in teaching and learning. More specifically, students argued that the adoption of SNSs helped them to have access to information and learning resources, receive good support from their peers and professors, and have good participation in course activities. This had a good impact on their knowledge construction and critical refection as well as on their overall perceptions and experience. However, students did not have good experience with SNSs for assessment and feedback. This supports a previous study [3] that SNSs, e.g., Facebook and WhatsApp, are appropriate platforms for learning and supporting students but they are not an appropriate tool for assessing their academic performance and giving students feedback. Students may need to receive detailed feedback privately, not in-group, and did not find SNS groups, i.e., WhatsApp and Facebook groups, sufficient for this purpose.

Students also found MS Teams helped them to gain appropriate learning experience. Similar to their perceptions of courses provided by SNSs, students argued that that MS Teams helped them to have access to information and learning resources. However, unlike SNSs, students found MS Teams helped them to receive appropriate assessment and feedback on their academic performance. This had a good impact on their critical refection and on their overall perceptions and experience. One the other side, students argued that they did not have good support and participation in activities using MS Teams. This meant that they did not find MS Teams to be a sufficient tool to receive proper support and to participate in course activities. Therefore, the magnitude of the differences between experience with SNSs and MS Teams was very large in support, participation, assessment, and feedback and very small in other items. These results have several implications for policymakers, educators, and scholars as will be discussed in the next two sections.

\subsection{Implications for Policymakers and Educators}

The results have several impactions for policymakers and educators in higher education, especially in relation to public higher education in developing countries. The integration of online learning in higher education is necessary to cope with unexpected crises, e.g., the COVID-19 pandemic. Hence, policymakers of higher educations in developing countries need to set a policy for online learning. Since public institutions in developing countries are suffering from limited resources, poor infrastructure, and unavailability of DLMS, the policy could adopt low-cost communication platforms, e.g., SNSs and MS Teams. The current research showed SNSs encourage students to participate more in course activities and receive support from their peers and professors, whereas they would have a good experience with MS Teams for assessing their knowledge and receiving proper feedback on their academic performance. Hence, integration of both SNSs and MS Teams would lead to a positive and unique learning experience.

A sufficient training and workshops for both educators and students need to be provided on how they could properly use MS Teams and to maximize students' support and participation in activities, which was found insufficient in the current study. It crucial that both educators and students have a supporting manual and videos on how to use MS Teams for teaching and learning purposes. The availability of toolkits and brochures for 
educators and students on how they could use MS Teams in parallel with the use of SNSs for supporting teaching and learning purposes is crucial. Students' learning experience should be assessed by institutions regularly to handle any deficiencies or problems that could affect students' experience. An ICT support unit needs to be added to each institution to help both educators and students cope with this new culture of online learning amid COVID-19, since they used to employ face-to-face education.

\subsection{Implications for Scholars}

The results also send important messages to scholars. Previous research studies either explored students' perceptions of distance education during COVID-19 and its influences on students' academic performance (e.g., [4,5,36]), especially the adoption of MS Teams amid COVID-19 (e.g., [32,39,40]) or examined the use of SNSs for sustaining education during this uncertain time (e.g., [3]). This research, however, compares students' learning experiences within two different platforms (i.e., SNSs and MS Teams), which were adopted for teaching and learning amid COVID-19. The current research showed that although students have an overall good experience with courses incorporating SNSs, they did not find SNSs appropriate for assessing their academic performance and receiving proper feedback. Additionally, students did not find MS Teams to be a good tool for receiving support from their peers and professors. This confirms that there is no single perfect platform to create a unique learning experience, and thus a mixture of platforms or tools would lead to a better learning experience. It is crucial to understand how assessment and feedback using SNSs could be improved. On the other side, it important to investigate how support and participation using MS Teams could be ensured.

\section{Limitations and Future Research}

The current research focused only on public institutions in Egypt, especially those offering tourism and hotels degree where some of the research team are working. Hence, although there were some interesting findings about the use of SNSs and MS Teams to ensure proper learning experience in the absence of formal DLMS and face-to-face education, the results could be limited to these institutions and other institutions of same features and culture. It is, therefore, suggested that that these results could be examined in other institutions in different countries. Further research could be directed at improving support and participation of students using MS Teams. Additionally, further research could examine how to improve assessment and feedback using SNSs.

Author Contributions: Conceptualization, A.E.E.S. and A.E.A.E.; data curation, A.E.E.S., A.E.S., A.E.A.E. and A.M.H.; formal analysis, A.E.E.S. and A.E.A.E.; investigation, A.E.E.S., A.E.S., and A.E.A.E.; methodology, A.E.E.S., A.E.S., A.E.A.E. and A.M.H.; project administration, A.E.E.S. and A.E.A.E.; resources, A.E.E.S., A.E.S. and A.M.H.; software, A.E.E.S. and A.E.A.E.; supervision, A.E.A.E.; validation, A.E.E.S., A.E.S. and A.M.H.; visualization, A.E.E.S. and A.E.A.E.; writingoriginal draft, A.E.E.S., A.E.S., A.E.A.E. and A.M.H.; writing-review and editing, A.E.E.S. and A.E.A.E. All authors have read and agreed to the published version of the manuscript.

Funding: This research received no external funding.

Institutional Review Board Statement: Not applicable.

Informed Consent Statement: Not applicable.

Data Availability Statement: Data available on request due to privacy/ethical restrictions.

Conflicts of Interest: The authors declare no conflict of interest.

\section{References}

1. Sobaih, A.; Moustafa, M.; Ghandforoush, P.; Khan, M. To use or not to use? Social media in higher education in developing countries. Comput. Hum. Behav. 2016, 58, 296-305. [CrossRef]

2. Hsieh, Y. The Most Sustainable Niche Principles of Social Media Education in A Higher Education Contracting Era. Sustainability 2020, 12, 399. [CrossRef] 
3. Sobaih, A.; Hasanein, A.; Abu Elnasr, A. Responses to COVID-19 in Higher Education: Social Media Usage for Sustaining Formal Academic Communication in Developing Countries. Sustainability 2020, 12, 6520. [CrossRef]

4. Jacques, S.; Ouahabi, A.; Lequeu, T. Synchronous E-learning in Higher Education during the COVID-19 Pandemic. In Proceedings of the 2021 IEEE Global Engineering Education Conference (EDUCON), Vienna, Ausria, 21-23 April 2021; pp. 1102-1109.

5. Jacques, S.; Ouahabi, A.; Lequeu, T. Remote Knowledge Acquisition and Assessment During the COVID-19 Pandemic. Int. J. Eng. Pedagog. 2020, 10, 120-138. [CrossRef]

6. Basilaia, G.; Kvavadze, D. Transition to Online Education in Schools during a SARS-CoV-2 Coronavirus (COVID-19) Pandemic in Georgia. Pedagog. Res. 2020, 5, 1-9. [CrossRef]

7. Rashid, S.; Yadav, S. Impact of COVID-19 pandemic on higher education and research. Indian J. Hum. Dev. 2020, 14, 340-343. [CrossRef]

8. HyeJeong, K. The Efficacy of Zoom Technology as an Educational Tool for English Reading Comprehension Achievement in EFL Classroom. Int. J. Adv. Cult. Technol. 2020, 8, 198-205.

9. Williamson, B.; Eynon, R.; Potter, J. Pandemic Politics, Pedagogies and Practices: Digital Technologies and Distance Education during the Coronavirus Emergency. Learn Media Technol. 2020, 45, 107-114. [CrossRef]

10. Porter, B.; Grippa, F. A Platform for AI-Enabled Real-Time Feedback to Promote Digital Collaboration. Sustainability 2020, 12, 10243. [CrossRef]

11. Sukendro, S.; Habibi, A.; Khaeruddin, K.; Indrayana, B.; Syahruddin, S.; Makadada, A.; Hakim, H. Using an Extended Technology Acceptance Model to Understand Students' Use of e-Learning during COVID-19: Indonesian Sport Science Education Context. Heliyon 2020, 6, e05410. [CrossRef] [PubMed]

12. Abbasi, S.; Ayoob, T.; Malik, A.; Memon, I. Perceptions of students regarding E-learning during COVID-19 at a private medical college. Pak. J. Med. Sci. 2020, 36, S57-S61. [CrossRef]

13. Sobaih, A.; Moustafa, M. Speaking the same language: The value of social networking sites for hospitality and tourism higher education in Egypt. J. Hosp. Tour. 2016, 28, 21-31. [CrossRef]

14. Manca, S. Snapping, pinning, liking or texting: Investigating social media in higher education beyond Facebook. Internet High Educ. 2020, 44, 100707. [CrossRef]

15. Klein, A.; Junior, J.; Barbosa, J.; Baldasso, L. The Educational Affordances of Mobile Instant Messaging (MIM): Results of Whatsapp®Used in Higher Education. Int. J. Distance Educ. Technol. 2018, 16, 51-64. [CrossRef]

16. Deng, L.; Tavares, J. From Moodle to Facebook: Exploring students' motivation and experiences in online communities. Comput Educ. 2013, 68, 167-176. [CrossRef]

17. Jong, B.-S.; Lai, C.-H.; Hsia, Y.-T.; Lin, T.-W.; Liao, Y.-S. An exploration of the potential educational value of Facebook. Comput. Hum. Behav. 2014, 32, 201-211. [CrossRef]

18. Awidi, I.; Paynter, M.; Vujosevic, T. Facebook group in the learning design of a higher education course: An analysis of factors influencing positive learning experience for students. Comput. Educ. 2019, 1, 106-121. [CrossRef]

19. Valenzuela, S.; Park, N.; Kee, K. Is there social capital in a social network site?: Facebook use and college students' life satisfaction, trust, and participation. J. Comput. Mediat. Comm. 2009, 14, 875-901. [CrossRef]

20. Lambić, D. Correlation between Facebook use for educational purposes and academic performance of students. Comput. Hum. Behav. 2016, 61, 313-320. [CrossRef]

21. Durak, H. Examining the acceptance and use of online social networks by preservice teachers within the context of unified theory of acceptance and use of technology model. J. Comput. High. 2019, 31, 173-209. [CrossRef]

22. Dyson, B.; Vickers, K.; Turtle, J.; Cowan, S.; Tassone, A. Evaluating the use of Facebook to increase student engagement and understanding in lecture-based classes. J. High. Educ. 2015, 69, 303-313. [CrossRef]

23. Bowman, N.; Akcaoglu, M. "I see smart people!": Using Facebook to supplement cognitive and affective learning in the university mass lecture. Internet High Educ. 2014, 23, 1-8. [CrossRef]

24. Cuesta, M.; Eklund, M.; Rydin, I.; Witt, A. Using Facebook as a co-learning community in higher education. Learn. Media Technol. 2016, 41, 55-72. [CrossRef]

25. Sarapin, S.; Morris, P. Faculty and Facebook friending: Instructor-student online social communication from the professor's perspective. Internet High Educ. 2015, 27, 14-23. [CrossRef]

26. Sheeran, N.; Cummings, D. An examination of the relationship between Facebook groups attached to university courses and student engagement. High. Educ. 2018, 76, 937-955. [CrossRef]

27. Junco, R. Student class standing, Facebook use, and academic performance. J. Appl. Dev. Psychol. 2015, 36, 18-29. [CrossRef]

28. Manca, S.; Ranieri, M. Facebook and the others. Potentials and obstacles of social media for teaching in higher education. Comput. Educ. 2016, 95, 216-230. [CrossRef]

29. Poston, J.; Apostel, S.; Richardson, K. Using Microsoft Teams to Enhance Engagement and Learning with Any Class: It's Fun and Easy. Pedagog. Conf. Proc. 2020, 6, 1-7.

30. Hubbard, M.; Bailey, J. Mastering Microsoft Teams. In Mastering Microsoft Teams; Springer: Berlin/Heidelberg, Germany, 2018. [CrossRef]

31. McVey, M.; Edmond, A.; Montgomery, D. Supporting Students to Develop their Digital Literacies using Microsoft Teams. In Proceedings of the ALT Winter Conference, online. 11-12 December 2019; Available online: http:/ / eprints.gla.ac.uk/206468/ (accessed on 28 July 2021). 
32. Henderson, D.; Woodcock, H.; Mehta, J.; Khan, N.; Shivji, V.; Richardson, C.; Aya, H.; Ziser, S.; Pollara, G.; Burns, A. Keep Calm and Carry on Learning: Using Microsoft Teams to Deliver a Medical Education Program during the COVID-19 Pandemic. Future Healthc. J. 2020, 7, 1-4. [CrossRef]

33. Lorenzi, M.; Riley, T. Managing change: An overview. J. Am. Med. Inf. Assoc. 2000, 7, 116-124. [CrossRef]

34. Vitoria, L.; Mislinawati, M.; Nurmasyitah, N. Students' perceptions on the implementation of e-learning: Helpful or unhelpful? J. Phys. Conf. Ser. 2018, 1088, 12058. [CrossRef]

35. Mulyasa, M. Persepsi Mahasiswa atas Penggunaan Aplikasi Pembelajaran Daring Saat Wabah COVID 19. J. Anal. Sist. Pendidik. Tinggi 2020, 4, 47-56.

36. Krishnapatria, K. From 'lockdown' to letdown: Student's Perception of e-learning amid the COVID-19 Outbreak. ELT Focus 2020, 3, 1-8. [CrossRef]

37. Brahma, A. Penggunaan Zoom Sebagai Pembelajaran Berbasis Online dalam Mata Kuliah Sosiologi dan Antropologi pada Mahasiswa PPKN di STKIP Kusumenegara Jakarta. J. Ilmu Pendidik. Nonform. 2020, 6, 97-102. [CrossRef]

38. Hapsari, S.; Pamungkas, H. Pemanfaatan Google Classroom Sebagai Media Pembelajaran Online di Universitas Dian Nuswantoro Wacana J. Ilm. Ilmu Komun. 2019, 18, 225-233. [CrossRef]

39. Wea, N.; Kuki, A. Students' Perceptions of Using Microsoft Teams Application in Online Learning During the COVID-19 Pandemic. J. Phys. Conf. Ser. 2021, 1842, 012016. [CrossRef]

40. Nguyen, H.U.N.; Duong, L.N.T. The Challenges of E-learning Through Microsoft Teams for EFL Students at Van Lang University in COVID-19. AsiaCALL Online J. 2021, 12, 18-29.

41. Rojabi, A.R. Exploring EFL Students' Perception of Online Learning via Microsoft Teams: University Level in Indonesia. Engl. Lang. Teach. Educ. J. 2020, 3, 163-173. [CrossRef]

42. Ismail, S.; Ismail, S. Teaching Approach using Microsoft Teams: Case Study on Satisfaction versus Barriers in Online Learning Environment. J. Phys. Conf. Ser. 2021, 1874, 12020. [CrossRef]

43. Evans, J.; Mathur, A. The value of online surveys. Internet Res. 2005, 15, 196-219. [CrossRef]

44. Adusei-Asante, K.; Awidi, I.; Doh, D. Improving retention and academic achievements of African students in higher education through community development. In Proceedings of the STARS Conference, Perth, Australia, 29 June-2 July 2016 ; p. 5.

45. Hair, J.; Black, W.; Babin, B.; Anderson, R. Multivariate Data Analysis, 7th ed.; Pearson Education: Upper Saddle River, NJ, USA, 2013.

46. Pallant, J. SPSS Survival Manual; McGraw-Hill Education: New York, NY, USA, 2013. 